\title{
Factors Influencing Student Satisfaction in Higher Education. The Case of a Georgian State University
}

\author{
Nino Tandilashvili \\ Associate professor, Ilia State University, Tbilisi, Georgia,nino.tandilashvili@iliauni.edu.ge
}

\begin{abstract}
With the increasing importance, higher education is considered as a major asset for any nation's socio-economic and technological development. The quality of education offered by the higher education institutions directly impacts country's performance. That is why, number of scientific researches and public reports and debates agrees on the importance of the quality management in higher education. There is also an important debate on a link between the service quality and students' satisfaction. On the one hand, there is a logical dependence of the degree of satisfaction to the perceived quality. On the other hand, number of studies have also identified a link between students' satisfaction and their loyalty. This study looks at the determinants of student satisfaction in Georgian Higher Education Institutions. With the objective to detect the main components of service quality influencing students' satisfaction, the article uses HEdPERF as a measuring instrument of higher education service quality. Data is collected from 793 students of one of the largest universities of the country. An exploratory factor analysis six factors for the further examination. After scale development, a multiple regression analysis is used to test the research hypothesis. The results of the study show that the administrative factors are the most sensitive and have a positive influence on the students' satisfaction. Also, there is a positive relation between academic programs and student's satisfaction. The disproportionate attitude is observed between the importance of academic factors and satisfaction.
\end{abstract}

KEYWORDS: service quality, customer perception, student satisfaction, HEdPERF, higher education

\section{Introduction}

Higher education, being one of the major assets for the development of any nation in the $21^{\text {st }}$ century, has turned into an important topic of scientific research. On the one hand, number of studies have demonstrated a positive impact of the investment in higher education on country's economic development (Coleman 2005). On the other hand, authors observe an increase of competition among higher education institutions (HEI). The competition is due to some complementary factors: globalization, increased number of HEI, modified funding schemes and global and national university rankings and league tables. These trends have pushed universities to fight for their competitive advantages on the global market (Quinn, Lemay, Larsen and Johnson 2009, 146), putting students' recruitment and retention in the top concerns of most university plans. In some countries student recruitment and retention are imposed by government targets as poor retention rates have adverse funding consequences for institutions, like this is the case in the UK, for example Thus recruitment, student satisfaction and retention are closely linked and student satisfaction has become an extremely important issue for universities and their management.

As a result of these recent evolutions in higher education, the quality of education has become a concern at governmental levels. Number of national associations/organisations have been established with the unique aim to enhance the quality of services provided by local higher education institutions and thus, improve countries' competitive advantages. The European Association for Quality Assurance in Higher Education (ENQA), was established in 2000 in order to represent quality assurance and accreditation organisations from the European Higher Education Area and internationally. The aim of the organisation is to improve the quality of higher education among the Bologna Process countries by elaboration of set of standards, procedures and guidelines for higher education institutions of these countries. In the USA, there are some similar organisations out which the Council for Higher education Accreditation (CHEA) is the most important. CHEA groups over 3,000 degree-granting colleges and universities and recognizes 60 institutional and programmatic accrediting organizations. 
Previous studies have shown that universities should to try to maximise students' satisfaction with their experience whilst they are at university and minimise dissatisfaction in order to retain students as well as to improve the institutions' performance across a number of league tables, so improve the external recruitment and internal retention rates (Blackmore et al. 2006; Douglas et al. 2006). Previous research has also demonstrated the need to study the topic within a national context due to cultural and socio-economic differences per country resulting in different factors influencing students' satisfaction and/or causing students' dissatisfaction.

The aim of the present research is to identify the factors that influence student satisfaction in a multidisciplinary HEI in Georgian higher education context. To do so a case study approach was privileged. Quantitative data was collected using HEdPERF framework. Most of previous studies have used SERVQUAL framework to assess students' satisfaction. However, some authors have found it "challenging" to use this universal instrument to take into account the diverse nature of higher education field. HEdPERF framework was introduced as a superior instrument in terms of unidimensionality, reliability, and validity, which explained variance within the higher education setting better in comparison to SERVPERF framework (Abdullah 2005).

The results of this research can help university management to improve the quality of academic and other services by providing a guidance framework that would allow focusing resources and efforts towards those areas that will improve most student satisfaction and reduce their dissatisfaction. The article consists of three main parts. It stars with the review of a theoretical framework within which this study positions. It continues with methodological part explaining the research method using in this study and finishes with the discussion of the main findings.

\section{Literature review}

Quality of education, student satisfaction and loyalty has been largely discussed and promoted in scientific literature, national debates as well as in strategies of higher education institutions since last couple of decades (Gruber et al. 2010; Temizer and Turkyilmaz 2012). These debates argue that there is a positive correlation between quality of education and students' satisfaction on the one hand, and the satisfaction and student loyalty on the other hand. In the scientific literature, these concepts are studied within the framework of customer satisfaction of service quality, i.e. a combination of emotional and cognitive reactions concerning a particular focus which takes place at a particular period of time (Giese and Cote 2000, 16).

Broadly speaking, customer satisfaction can be viewed from two basic constructs: satisfaction as meeting customers' expectations they had prior to purchase or after the use of products and services; and satisfaction as customers' relative perception of the performance of those products or services after using them. A customer's expectations about a product tells how he/she anticipates product's performance. In this logic, satisfaction is a state that a human being experiences when he receives the product of his expectation (Hasan et al. 2008). Authors suggest that there are different types of expectations when forming opinions about a product's anticipated performance. Day proposed four types of expectations customers have about a product: expectation about the costs, the product nature, the efforts in obtaining benefits and social value of the product (Day 1977).

On the other hand, a perceived product performance is considered as an important construct of evaluating customer satisfaction, due to its ability to make comparisons with expectations. In this sense, satisfaction is the perceived benefit minus the expected benefit of the product. When this equation is positive, we can talk about a satisfaction state (Grönroos 1984; Lewis and Booms 1983; Smith and Houston 1982). The relationship between quality and satisfaction is not straightforward. Some early researchers argued that customer satisfaction is a precursor of service quality (Bitner 1990; Parasuraman et al.1988) while others claimed that it is service quality that leads to customer satisfaction (Hoisington and Naumann 2003; Douglas et al. 2016).

Applied to the context of higher education, the debate on the relationship between the quality of service and satisfaction of customers is even more sensitive than in other industries. There is an important debate on who is the customer of higher education institution. For some, a customer of higher education is a student receiving the education (Hill 1995, 18). For others, academic staff, 
employers, and public sector should also be considered as customers of higher education (Kanji at al. 1999) as they also (if not exclusively in some countries) pay for the service received by the students. The concept of student as a customer is not new. However, as the relation between supplier-customer is not as clear in higher education as in other sectors (Douglas et al. 2006) there is a diverse opinion on the nature of customer in this field.

Another debate around the student satisfaction concept is the viability to actually judge the quality of education. Some argue that a student is not capable of objectively judge the quality of education he receives as he is still under the process of forming skills and knowledge. Putting these important topics aside in this research, the article continues with the assumption that knowing the factors that influence students' satisfaction can help higher education institutions improve their services (El-Hilali, Al-Jaber, Hussein 2014, 426) and/or create competitive advantages on the global marketplace. This topic is particularly important in a context of limited resources and strategic choices that HEI face (Abdullah 2005; Douglas et al. 2006).

The HEI management needs to make very delicate distinction between whether their objective of HEI should be to deliver satisfied customers, who will then develop a perception of high service quality, or that they should aim for high service quality as a way of increasing customer satisfaction. Higher education service quality is a product of number of various services that students encounter within the HEI. Hill stated that such services are provided by administrators, teaching staff and managers as well as other HE employees (Hill 1995).

As demonstrated by number of studies, it is more expensive to attract new customers than to maintain the existing ones (Gemme 1997, 19-21). Researchers perceive customer loyalty to be influenced by satisfaction, even if the structure of the relationship does not appear to be symmetric and linear (Mittal et al. 1998). As explained by Kotler and Amstrong, a long-term relationship with a customer is based on satisfying his upmost values and that is why it is particularly difficult to achieve. However, having loyal customer also benefits businesses financially in short- and longterm perspectives (Kotler and Amstrong 2015,13). The same can be said about the cost of attracting new students and the benefits they can generate. DeShields, Kara, and Kaynak (2005, 128-139) illustrated that loyal students benefit universities not only with the tuition fees they pay, but also thanks to the reputation and the power of word of mouth promotion. Another advantage is that a satisfied student is loyal to his institution not only during but also after his studies and assist their alma mater in different ways (Gibson 2010).

Douglas et al. $(2006,251-267)$ consider that the loyalty of a student can be reviled in different scenarios: decision to continue studies in the same institution; frequent usage of different services of the institution and recommending the institution to others. Thus, studying the satisfaction elements as well as those dissatisfying students is important step to assess the quality perception of university services. It can guarantee higher loyalty to HEI. The key question to start this study is thus, what are the factors that improve students' satisfaction. The next part of the literature review will investigate further this question.

\section{Factors influencing student satisfaction}

Previous studies have identified two sets of factors impacting the satisfaction level of students: factors that positively impact satisfaction and factors that dissatisfy students. The satisfier factors, on its turn, can be grouped within purely academic elements and elements that are linked with other services provided by higher education institutions. Some argue that these two sets of satisfier factors are linked and should be studied together. A recent study by Herdlein and Zurner (2015) showed that students who are more involved in extra curriculum activities, such as sport event, organisational activities, social gathering, etc. are more satisfied compared to those who do not participate in any extra curriculum activities. According to Akil, $80 \%$ of students in Europe express the importance of these activities and often is the decision point when considering a future institution for their education. European students also express higher satisfaction when they are confronted to a multinational learning environment (cited by Herdlein and Zurner 2015). 
Studies in European universities found that student satisfaction was largely influenced by the possibility given by higher education institutions to prepare them for a concrete profession, as well as their social, emotional and physical preparation (Herdlein and Zurner 2015). Some students consider that the possibility to meet new friends and develop network for future is essential function of a HEI (Cook and Rushton 2008). This social mission of modern university is also highlighted by other studies according to which, university campus should be planned in such a way to allow students live and study together and share knowledge and experience (Ping 1999, 16).

Student satisfaction seem to vary per discipline and student profiles (Coates 2008). For example, a study by Coates showed that the satisfaction level is relatively law among international students, also students who are aged 22 to 30 and students who study management, commerce and information technologies. The same study also showed that relatively higher satisfaction could be explained by good relation of students with academic and administrative staff and with other students (Coates 2008). A study by Marzo-Navarro et al. (2005, 53-65) also identified some demographic characteristics which explain the different level of satisfaction in the higher education field: age, gender, ethnic origin and level of education. Other studies showed that the satisfaction level may vary per disciplinary background, religion and learning style in additional to some of the previously listed factors (Berg et al. 2010; Limon 2001).

One of the findings of previous studies suggest a positive relation between satisfaction and academic performance (Rode et al. 2005). Some studies have shown that students with high performance (good grades) demonstrate more satisfaction than those with poorer academic results (Lo 2010). Studies have shown that students' academic performance largely depend on the learning environment they work in, such as small size classes, problem solving exercises (Johnson, Johnson \& Smith 2007, 15-29). Positive environment motivates students to exceed their performance and makes them satisfied (Ocker and Yaverbaum 2001, 427-448).

There are number of factors that influence students' dissatisfaction instead of satisfaction. These factors are sometimes coming from outside the HEI, such as health issues, financial difficulties and family related problems (Thompson \& Prieto 2013). Others are directly linked with the institutions, like the perceived lack of quality of education, high tuition fees, disappointing learning environment and university reputation, inflexible schedule, bad location of intuition, etc. (Melinget al. 2012). Some studies showed that the level of dissatisfaction also depends on the little possibility of employment after the graduation (Gbadosami \& De Jager 2010) and lack of engagement in academic and non-academic projects of their institutions (Garcia-Aracil 2009).

Previous studies have suggested that cultural and socio-economic differences may result in different perception and expectation of education quality. A study realized by LeBlanc and Nguyen 1997) in Canada showed that students' satisfaction depends on tuition fee and possibility of personal development in addition to the quality of service they receive. A study in Pakistan showed four priority services for the satisfaction in Pakistani higher education system: qualification level of academic staff, proposed curriculum, learning environment and classroom atmosphere (Zaheer and Rehman 2010). Somewhat different results were founded in a study realised in Iran. Students' satisfaction in Tehrani universities seems to be impacted by factors such as the effectiveness of academic consultation, the services provided at the campus, student life, respect to ethnical diversity, security and possibilities to have financial support (Khosravi, Poushaneh, Roozegar and Sohrabifardd 2013).

\section{HEdPERF tool of service quality evaluation in higher education field}

The difficulty to evaluate the quality of service in general has been largely discussed in scientific literature (Brady and Cronin 2001). There has been number of tools and models created with this purpose since the 1980s, like Service (perceived) quality model (Gronroos 1984); SERVQUAL (Parasuraman et al. 1988); SERVPERF (Cronin \& Taylor 1992); Three-component service quality model (Rust and Oliver 1994, 1-19); Multi-level model (Dabholkar et al. 1996, 3-16) and Hierarchical model (Brady and Cronin 2001, 34-49). 
These models are based on either qualitative, quantitative or mixed variables and apply to different industries. Each of these tools were created with an objective to more accurately judge the quality than the previous one (Othman \& Owen 2001). SERVPERF, for example, was elaborated as an improvement of commonly used SERVQUAL as SERVPERF manages to identify more differences in the total result of a service quality evaluation (Cronin \& Taylor 1994, 129) and prioritizes the perception over expectation (Boulding et al. 1993, 7-27). It has also been argued that an objective and in-depth evaluation of different service fields, requires models created exclusively for particular fields (Vazirova 2016). With this aim, number of industry-based tools have been created. The table 1 lists these tools in a chronological order.

Table 1. Service quality evaluation models for different industries

\begin{tabular}{|c|c|c|}
\hline Model & Author & Industry of application \\
\hline SERVPERF & Cronin \& Taylor 1992 & Hotel, clubs, tourism agencies \\
\hline DINESERV & Stevens, Knutson \& Patton 1995 & Restauration \\
\hline LONGSERV & Knutson, et.al. 1990 & Hotels \\
\hline SERVERVAL & Petrick 2002 & Airlines \\
\hline SYSTRA-SQ & Aldalaigan \& Buttle 2002 \\
\hline SITEQUAL & Yoo \& Donthu 2001 & E-commerce \\
\hline E-SQUAL & Parasuraman et.al. 2005 & E-commerce \\
\hline HEdPERF & Abdullah 2006 & Higher education \\
\hline SELEB & Toncar et.al. 2006 & Education services \\
\hline
\end{tabular}

Researchers use either generic tools, like SERQUAL to evaluate higher education services, or apply specific models, like HEdPERF. The later was originally created in 2003 and shaped as it is now in 2006. The main aim of the tool is to propose industry-based evaluation to the top management of higher education institutions. The instrument was empirically tested for unidimensionality, reliability and validity using both exploratory and confirmatory factor analysis. Later studies confirmed that HEdPERF results were more accurate than those of SERVPERF, for example, when it evaluated higher education institutions (Randheer 2015, 35). The model views student perceptions of service quality as a six-factor structure consisting of 41 variables covering academic and administrative aspects of higher education. The variables are grouped into six main dimensions:

1. Non-academic aspects - all elements that are essential for the processes of education and are linked with the duties of non-academic staff of higher education institutions;

2. Academic aspects - the competences of academic staff, their duties and responsibilities;

3. Reputation - the image of the institution;

4. Access - approachability, ease of contact, availability and convenience of higher education institution;

5. Programme aspects - importance of offering wide range and reputable academic programmes with flexible structures and syllabus.

6. Understanding - understanding students' specific need in terms of counselling and health services (Abdullah 2006, 575).

As we have seen above, students perceive the quality of higher education service as a collection of different services (Douglas et al. 2006; Herdlein and Zurner 2015). HEdPERF tool allows to identify the variety of elements that can lead to higher satisfaction of students. The review of literature has shown 
the importance of considering students' experience in a higher education institution as a key issue for institutional strategy as satisfied students lead to higher financial and reputational benefits to HEI and allows them to more successfully position in an increasingly competitive marketplace. Thus the objective of the present research is to identify the elements that lead to students' satisfaction in a multidisciplinary higher education institution and provide recommendations to the management of HEI regarding the direction to allocate their resources and efforts.

\section{Research methodology}

The choice of Ilia State University as the case of our research was determined by its specific nature. With 14602 student, Ilia State University is one of the biggest higher education institutions in the Caucasus region. University was created 15 years ago after a merger of four half-century-old universities. Today university consists of four faculties: Faculty of Business, Technology and Education (45\% of total students), Faculty of Arts and Science (37\%), Faculty of Natural sciences and Medicine (8\%) and the School of Law (10\%), delivering education at bachelor, master and $\mathrm{PhD}$ levels. These faculties have diverse history and traditions. Their unification under the same roof went relatively smoothly but did not end up in close relations. Students experience common institutional structure but have different disciplinary practices. Thus, with the selecting a multidisciplinary institution, we hoped to observe, different perception of quality and satisfaction degree as well as the factors influencing satisfaction.

As our research emphasizes exploring commonalities in the study population, measurement and variables play an important role. A quantitative research approach was thus privileged in this study, using HEdPERF framework (Abdullah 2006). In order to 1) refine the research hypothesis and 2) get in-depth understanding of the research case, three focus groups were held with Ilia State University students and alumni. Each focus group lasted one hour and a half. Ten participants of each group (students and alumni) were rigorously selected: representing all three levels of education and all four faculties of the institution).

The focus group meetings reviled some interesting aspects concerning the perception of quality of services received by students. On the positive side, the interviewees mentioned five elements: orientation of the university towards modern teaching trends; intraorganizational platform for lecturer-student interaction; professionalism of academic staff; possibilities to do exchange programmes; and large choice of study programs. On the other hand, the interviewees mentioned also five negative points, like lack of student spaces (computer lab, after-school activities, etc.); curriculum of study programs; less flexible study timelines; technical issues with the intranet during the online selection of courses; and lack of employment possibilities. Results of the focus groups and the review of literature allowed pose the following hypothesis for this research:

Hypothesis 1: Positive reputation of study programmes increases students' satisfaction;

Hypothesis 2: There is a different satisfaction level in different disciplines;

Hypothesis 3: There is a difference satisfaction level per age group;

Hypothesis 4: Students with no experience of other higher education institutions are more satisfied than those with experience;

Hypothesis 5: Perceived quality of academic aspects explains the satisfaction level;

Hypothesis 6: Non-academic services are as important as academic aspects for students' satisfaction;

Hypothesis 7: Satisfied students are more loyal to HEI;

Hypothesis 8: Environment and location of university explains students' satisfaction.

The survey was realized in 2018 during a one-month period. We selected a period when students were not busy with exams or any major curriculum activities. To guarantee the equal and independent representation for each element of the study population, we opted for random sampling method (Kumar 2014). We used disproportionate stratified sampling in order to assure the representation of all disciplinary fields from the university without taking into consideration the size of each stratum (Kumar 2014). 
Our study population consists of 14602 students at bachelor, master and $\mathrm{PhD}$ level. We received 793 questionnaires out of which 783 were retained for analysis, making 95\% confidence limits of the normal distribution (mean difference $\pm 1.96 \mathrm{SD}$ ) and 3\% margin error. Absolute majority of the study population is feminine (up to 80\%). 296 respondents $(37.8 \%$ ) are under 20 years old. 409 represent the age group of $21-25$ making the majority of the study population $(51.9 \%)$. Only 61 students are 26-30 years old (7.8\%) and 15 students between 31 and $35(1.9 \%)$. Five students are over 36 years old $(0.6 \%) .53,1 \%$ of respondents are employed and $(7.8 \%)$ are self-employed against $40.1 \%$ unemployed population. The table 2 presents the student repartition per study level.

Table 2. Representation of study population per study level

\begin{tabular}{|c|c|c|c|c|c|}
\hline & Year 1 & Year 2 & Year 3 & Year 4 & Total \\
\hline Bachelor & 143 & 155 & 121 & 187 & 606 \\
\hline Master & 75 & 95 & - & - & 170 \\
\hline Doctorate & 3 & 1 & 2 & 1 & 7 \\
\hline Total & 221 & 251 & 123 & 188 & 783 \\
\hline
\end{tabular}

The survey was distributed online to the entire student population with the help of university administration. 39 variables were retained out of 41 for this study. The survey data was analysed with STATA tool using factor analysis and regression.

\section{Data Analysis and main findings}

Looking for grouping variables into conceptually similar and significant clusters, a first component analysis was performed using Promax rotation and Kaiser normalization. The Promax method was privileged as the research aimed to identify a link between the independent variables. This step showed a positive correlation between HEdPERF variables and thus there was no need to additionally run Varimax method. For more reliability the choice was made to select only the factors with Eigenvalue higher or equal to 1 (Kumar 2014). Thus, the orthogonal analysis of 39 variables gave 3 main factors for further analysis as demonstrated in the table 3.

Table 3. Factor analysis of the

\begin{tabular}{|c|c|c|c|c|}
\hline Factor & Eigenvalue & Difference & Proportion & Cumulative \\
\hline Factor1 & $\mathbf{1 7 . 5 9 8 8 8}$ & $\mathbf{1 4 . 9 5 7 2 3}$ & $\mathbf{0 . 6 8 5 5}$ & $\mathbf{0 . 6 8 5 5}$ \\
\hline Factor2 & $\mathbf{2 . 6 4 1 6 5}$ & $\mathbf{0 . 6 9 4 1 4}$ & $\mathbf{0 . 1 0 2 9}$ & $\mathbf{0 . 7 8 8 5}$ \\
\hline Factor3 & $\mathbf{1 . 9 4 7 5 1}$ & $\mathbf{1 . 0 5 6 8 7}$ & $\mathbf{0 . 0 7 5 9}$ & $\mathbf{0 . 8 6 4 3}$ \\
\hline Factor4 & 0.89064 & 0.26984 & 0.0347 & 0.899 \\
\hline Factor5 & 0.6208 & 0.08331 & 0.0242 & 0.9232 \\
\hline Factor6 & 0.53749 & 0.06024 & 0.0209 & 0.9441 \\
\hline Factor7 & 0.47725 & 0.09341 & 0.0186 & 0.9627 \\
\hline Factor8 & 0.38384 & 0.05102 & 0.015 & 0.9777 \\
\hline Factor9 & 0.33282 & 0.09237 & 0.013 & 0.9906 \\
\hline Factor10 & 0.24044 & 0.05568 & 0.0094 & 1 \\
\hline Factor11 & 0.18476 & 0.02216 & 0.0072 & 1.0072 \\
\hline Factor12 & 0.1626 & 0.01871 & 0.0063 & 1.0135 \\
\hline Factor13 & 0.1439 & 0.01279 & 0.0056 & 1.0191 \\
\hline Factor14 & 0.1311 & 0.01253 & 0.0051 & 1.0242 \\
\hline Factor15 & 0.11857 & 0.01765 & 0.0046 & 1.0289 \\
\hline Factor16 & 0.10092 & 0.01934 & 0.0039 & 1.0328 \\
\hline Factor17 & 0.08158 & 0.02098 & 0.0032 & 1.036 \\
\hline Factor18 & 0.0606 & 0.01302 & 0.0024 & 1.0383 \\
\hline
\end{tabular}




\begin{tabular}{|c|c|c|c|c|}
\hline Factor19 & 0.04758 & 0.01262 & 0.0019 & 1.0402 \\
\hline Factor20 & 0.03496 & 0.00704 & 0.0014 & 1.0416 \\
\hline Factor21 & 0.02792 & 0.0117 & 0.0011 & 1.0426 \\
\hline Factor22 & 0.01622 & 0.01128 & 0.0006 & 1.0433 \\
\hline Factor23 & 0.00494 & 0.00809 & 0.0002 & 1.0435 \\
\hline Factor24 & -0.00315 & 0.00478 & -0.0001 & 1.0433 \\
\hline Factor25 & -0.00794 & 0.01137 & -0.0003 & 1.043 \\
\hline Factor26 & -0.01931 & 0.00634 & -0.0008 & 1.0423 \\
\hline Factor27 & -0.02564 & 0.00982 & -0.001 & 1.0413 \\
\hline Factor28 & -0.03546 & 0.00859 & -0.0014 & 1.0399 \\
\hline Factor29 & -0.04405 & 0.00652 & -0.0017 & 1.0382 \\
\hline Factor30 & -0.05056 & 0.00438 & -0.002 & 1.0362 \\
\hline Factor31 & -0.05494 & 0.00937 & -0.0021 & 1.0341 \\
\hline Factor32 & -0.06432 & 0.01635 & -0.0025 & 1.0316 \\
\hline Factor33 & -0.08067 & 0.00936 & -0.0031 & 1.0284 \\
\hline Factor34 & -0.09003 & 0.00642 & -0.0035 & 1.0249 \\
\hline Factor35 & -0.09645 & 0.01259 & -0.0038 & 1.0212 \\
\hline Factor36 & -0.10904 & 0.01549 & -0.0042 & 1.0169 \\
\hline Factor37 & -0.12454 & 0.02147 & -0.0049 & 1.0121 \\
\hline Factor38 & -0.14601 & 0.01761 & -0.0057 & 1.0064 \\
\hline Factor39 & -0.16362 &. & -0.0064 & 1 \\
\hline
\end{tabular}

The three factors represent $13,37 \%, 11,96 \%$ and $11,74 \%$ of the whole dispersion, making up to $37,07 \%$. The table 4 and the diagram 1 show the squared loading matrix which confirm our choice of the three first factors over the others, as after the factor 3, each successive factor is accounting for smaller and smaller amounts of the total variance (Pallant 2001, 154).

Table 4. Loading matrix

\begin{tabular}{|c|c|c|}
\hline Factor & Variance & Proportion \\
\hline Factor1 & $\mathbf{1 3 . 3 7 0 9 7}$ & $\mathbf{0 . 5 2 0 9}$ \\
\hline Factor2 & $\mathbf{1 1 . 9 6 1 0 4}$ & $\mathbf{0 . 4 6 5 9}$ \\
\hline Factor3 & $\mathbf{1 1 . 7 3 9 6 9}$ & $\mathbf{0 . 4 5 7 3}$ \\
\hline Factor4 & 9.90575 & 0.3859 \\
\hline Factor5 & 9.1015 & 0.3545 \\
\hline Factor6 & 6.38973 & 0.2489 \\
\hline Factor7 & 5.71445 & 0.2226 \\
\hline Factor8 & 5.30128 & 0.2065 \\
\hline Factor9 & 4.12552 & 0.1607 \\
\hline Factor10 & 2.43289 & 0.0948 \\
\hline
\end{tabular}

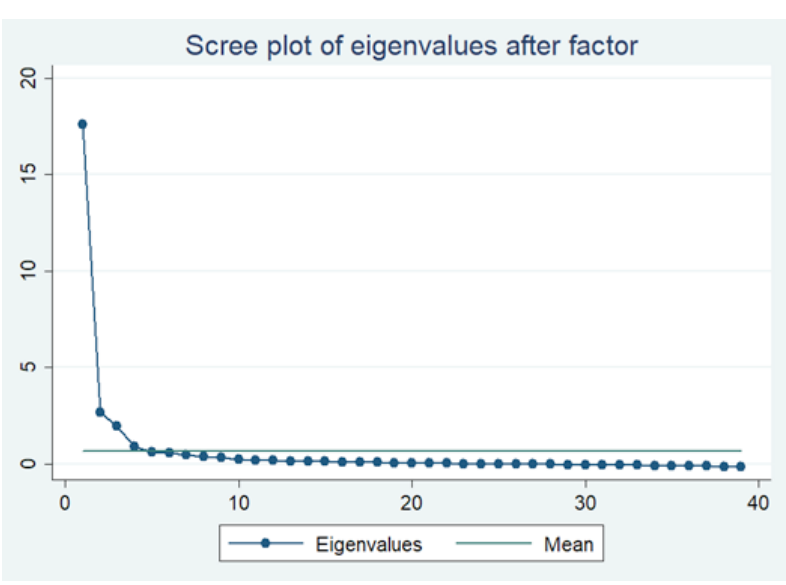

Diagram 1. Scree plot 1 
At the second step of our analysis, we identified the variables which constitute these three factors. As explained by Cohen, Manion and Morrison, it is important that each factor contains at least three variables (Cohen, Manion and Morrison 2007). The table 5 shows that, in accordance to the Promax rotation and Kaiser normalization tests, the first three factors consists of the highest number of variables. The factor 1 regroups variables B9 to B22 and concerns administrative services of the university. The second factor regroups variables B23 to B27 and B29 and concerns the curriculums and competitiveness of study programs, as well as student employability issues. The third factor contains first eight variables and concerns the academic aspects. The factors were named accordingly: Factor 1 Administrative aspects, Factor 2 - Study programmes and Factor 3 Academic staff.

Table 5. Factor analysis of 39 variables

\begin{tabular}{|c|c|c|c|c|c|c|c|c|c|c|c|}
\hline Variable & $\begin{array}{c}\text { Factor } \\
1\end{array}$ & $\begin{array}{c}\text { Factor } \\
2\end{array}$ & $\begin{array}{c}\text { Factor } \\
\mathbf{3}\end{array}$ & $\begin{array}{c}\text { Factor } \\
4\end{array}$ & $\begin{array}{c}\text { Factor } \\
5\end{array}$ & $\begin{array}{c}\text { Factor } \\
6\end{array}$ & $\begin{array}{c}\text { Factor } \\
7\end{array}$ & $\begin{array}{c}\text { Factor } \\
8\end{array}$ & $\begin{array}{c}\text { Factor } \\
9\end{array}$ & $\begin{array}{c}\text { Factor } \\
10\end{array}$ & Uniqueness \\
\hline var1 & & & 0317 & & & & 0560 & & & & 0 3814 \\
\hline var2 & & & 0.8278 & & & & & & & & 0.3042 \\
\hline var3 & & & 0.8129 & & & & & & & & 0.2553 \\
\hline var4 & & & 0.7904 & & & & & & & & 0.2627 \\
\hline var5 & & & 0.7755 & & & & & & & & 0.293 \\
\hline var6 & & & 0.7074 & & & & & & & & 0.3299 \\
\hline $\operatorname{var} 7$ & & & 0.6728 & & & & & & & & 0.3968 \\
\hline var8 & & & 0.5556 & & & & & & & & 0.442 \\
\hline var9 & 0.6383 & & & & & & & & & 0.4293 & 0.1762 \\
\hline var10 & 0.6415 & & & & & & & & & 0.4861 & 0.1276 \\
\hline var11 & 0.8077 & & & & & & & & & & 0.3397 \\
\hline $\operatorname{var12}$ & 0.8221 & & & & & & & & & & 0.3632 \\
\hline var13 & 0.72 & & & & & & & & & & 0.3639 \\
\hline var14 & 0.7602 & & & & & & & & & & 0.3491 \\
\hline $\operatorname{var} 15$ & 0.744 & & & & & & & & & & 0.2409 \\
\hline $\operatorname{var16}$ & 0.3964 & & & & & & & & & & 0.5795 \\
\hline $\operatorname{var17}$ & 0.7354 & & & & & & & & & & 0.2136 \\
\hline $\operatorname{var} 18$ & 0.5837 & & & & & & & & 0.3782 & & 0.3033 \\
\hline $\operatorname{var19}$ & 0.5095 & & & & & & & & 0.4391 & & 0.3359 \\
\hline $\operatorname{var} 20$ & 0.4132 & & & & & & & & 0.4261 & & 0.4204 \\
\hline $\operatorname{var} 21$ & 0.5094 & & & & & & & & & & 0.5219 \\
\hline $\operatorname{var} 22$ & 0.6756 & & & & & & & & & & 0.2974 \\
\hline $\operatorname{var} 23$ & & 0.7851 & & & & & & & & & 0.2747 \\
\hline $\operatorname{var} 24$ & & 0.8067 & & & & & & & & & 0.385 \\
\hline $\operatorname{var} 25$ & & 0.7408 & & & & & & & & & 0.3407 \\
\hline $\operatorname{var} 26$ & & 0.8967 & & & & & & & & & 0.1947 \\
\hline $\operatorname{var} 27$ & & 0.6273 & & & & & & & & & 0.3119 \\
\hline $\operatorname{var} 28$ & & & & & & & 0.5789 & & & & 0.2692 \\
\hline $\operatorname{var} 29$ & & 0.4672 & & & & & & & & & 0.6514 \\
\hline $\operatorname{var} 30$ & & & & & & & & 0.4448 & & & 0.3823 \\
\hline var31 & & & & & & & & 0.5173 & & & 0.4766 \\
\hline $\operatorname{var} 32$ & & & & & & 0.4352 & & & & & 0.5125 \\
\hline $\operatorname{var} 33$ & & & & & & 0.8319 & & & & & 0.2423 \\
\hline var34 & & & & 0.6085 & & & & & & & 0.2383 \\
\hline var35 & & & & 0.5745 & & & & & & & 0.2402 \\
\hline var36 & & & & 0.4364 & & & & & & & 0.4218 \\
\hline $\operatorname{var} 37$ & & & & & 0.3264 & & & & & & 0.4415 \\
\hline $\operatorname{var} 38$ & & & & & 0.8018 & & & & & & 0.2734 \\
\hline var39 & & & & & 0.5645 & & & & & & 0.3741 \\
\hline
\end{tabular}

The factor analysis revealed that when it comes to administrative aspects, the most important issues for students are 1) effective and quick response from administration to their complaints (B11) and 2) the readiness of administrative staff to assist students (B12). Less important components seem to be 1) comfortable working hours of administrative staff (B16) and 2) confidentiality respect from the administrative staff(B20). 
The quality of study programmes is assessed mainly by 1) large choice of study programmes and specializations (B24) and 2) the reputation of the offered programmes (B26). Less important for students while evaluating the quality of study programmes was the simplicity of employment after graduation (B29). As for the quality of academic staff, students judge it vital that 1) academic staff care about them and show respect (B2) as well as 2) their readiness to assist students (B3). Surprisingly, the less important aspect to evaluate the quality of academic aspects was the in-depth knowledge of the topic and the capacity to answer students' questions (B1).

\section{Correlation analysis}

Multiple regression was used in this study to determine the overall effect of different service dimensions on the service quality level, and to assess the relative importance of the individual dimensions. The regression model considered the service quality level as a dependent variable and the service quality scores for the individual dimensions as the independent variables. As commonly acknowledged, correlation is valid only with 0,5 or higher significance level in social studies (Kumar 2014). In accordance with the first two steps of our research, the same three factors showed the highest correlation level as demonstrated in the table 6. This step allowed us to investigate the main question of the research: the correlation between the quality university services perceived by the students, and the degree of their satisfaction.

Table 6. Correlation analysis of the top ten factors

\begin{tabular}{|c|c|c|c|c|c|c|c|c|c|c|}
\hline Factors & $\begin{array}{c}\text { Factor } \\
\mathbf{1}\end{array}$ & Factor2 & $\begin{array}{c}\text { Factor } \\
\mathbf{3}\end{array}$ & Factor4 & Factor5 & Factor6 & Factor7 & Factor8 & Factor9 & Factor10 \\
\hline & & & & & & & & & & \\
\hline Factor1 & $\mathbf{1}$ & & & & & & & & & \\
\hline Factor2 & $\mathbf{0 . 5 1 2 2}$ & $\mathbf{1}$ & & & & & & & & \\
\hline Factor3 & $\mathbf{0 . 5 7 2 4}$ & $\mathbf{0 . 5 4 0 9}$ & $\mathbf{1}$ & & & & & & & \\
\hline Factor4 & 0.545 & 0.6007 & 0.4851 & 1 & & & & & & \\
\hline Factor5 & 0.4753 & 0.5835 & 0.4848 & 0.5866 & 1 & & & & & \\
\hline Factor6 & 0.3835 & 0.5194 & 0.3301 & 0.4939 & 0.4149 & 1 & & & & \\
\hline Factor7 & 0.3381 & 0.507 & 0.4769 & 0.2775 & 0.4017 & 0.2396 & 1 & & & \\
\hline Factor8 & 0.3035 & 0.4839 & 0.3345 & 0.434 & 0.5052 & 0.4286 & 0.2302 & 1 & & \\
\hline Factor9 & 0.2924 & 0.3251 & 0.2926 & 0.3653 & 0.3523 & 0.3095 & 0.1929 & 0.2177 & 1 & \\
\hline Factor10 & 0.2676 & 0.09659 & 0.2962 & 0.1786 & 0.2547 & 0.217 & 0.1651 & 0.08864 & 0.2084 & 1 \\
\hline
\end{tabular}

The research fully confirmed hypothesis 5, 67 and 8 and partially confirmed hypothesis 1 and 3 . Hypothesis 2 and 4 were not confirmed within this study. The correlation analysis confirmed that purely academic factors (H5) are as important as non-academic one like the quality of administrative staff (H5) and reputation of study programmes (H1). However, other elements, like study environment and extracurriculum activities and spaces (H8) also showed as a major element in overall quality perception.

The research showed that administrative factors, more precisely the quality of administrative staff, is the most important factor while evaluating the overall university quality. Factor B11 "effective and quick response to students' complaints" plays the major role in evaluation of the administrative staff quality. However, the students seem to be the least satisfied with this component. Similarly, factor B12 "readiness of administrative staff to assist students" is second major element composing the quality of administrative staff. However, our study showed that students are not absolutely satisfied with this component. An opposite correlation was observed regarding the factor B20. Students are particularly satisfied with the "confidentiality respect from the administrative staff" but for them this is not the key element to judge the quality of university administration. 
Figure 1. Correlation between the perceived quality of administrative aspects and the level of satisfaction

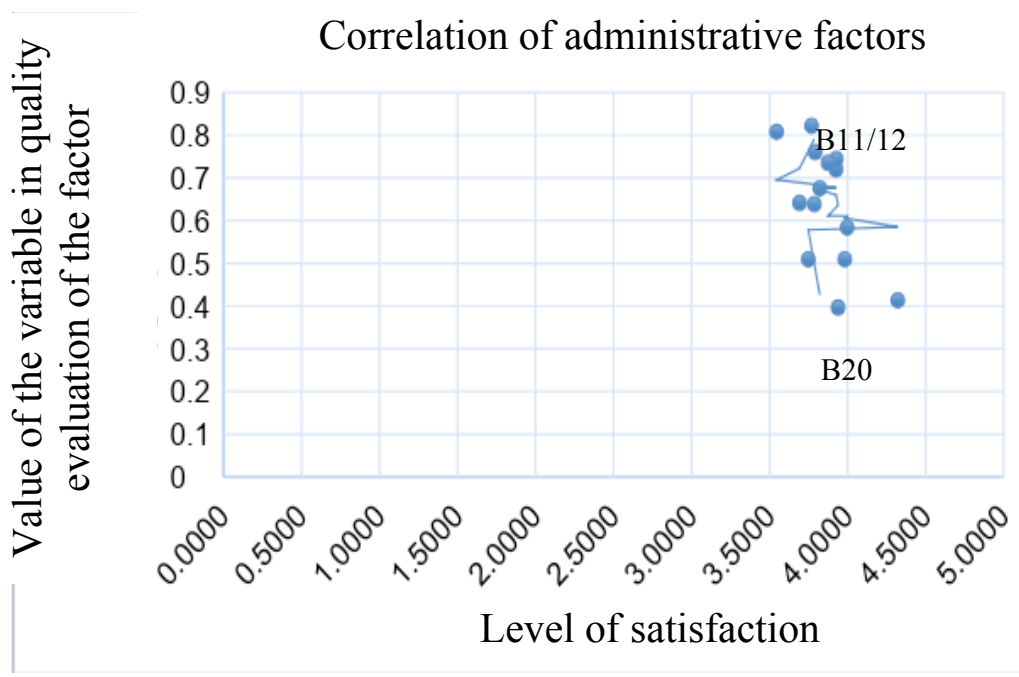

An opposite result was observed at the level of academic factors. Even if the studied population is particularly satisfied with the factor B1 "in-depth knowledge of the topic and the capacity to answer students' questions", for them this element is not essential while evaluating the quality of university services. This result coincides with the literature review where we observe the increase of importance of non-academic factors vis-à-vis academic considerations.

Figure 2. Correlation between the perceived quality of academic staff and the level of satisfaction

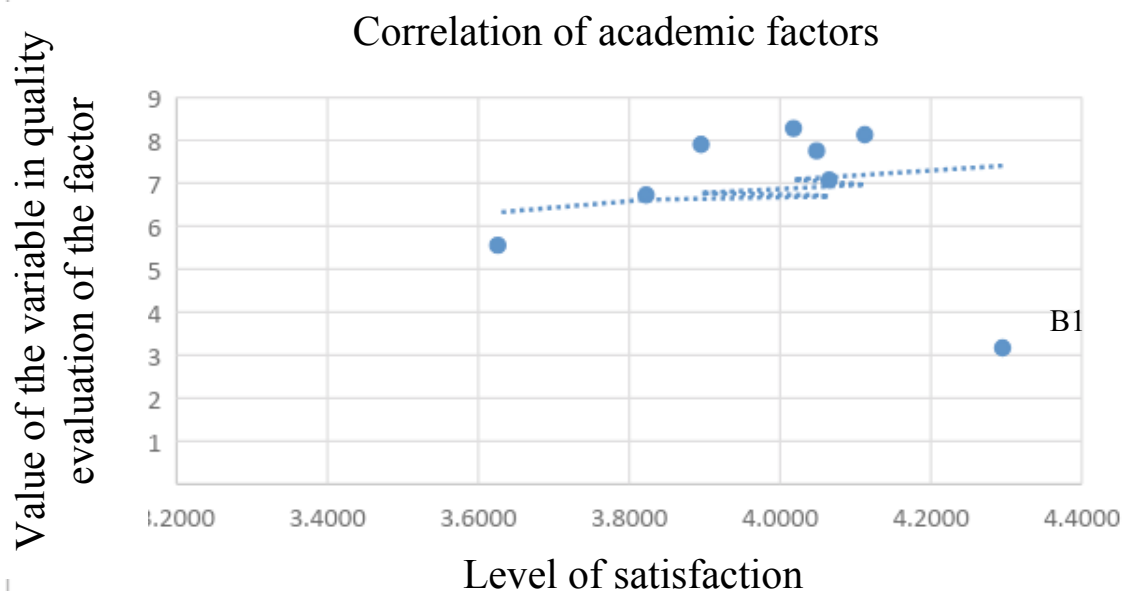

As for the academic programme factor, we observe a positive correlation between the perception of quality and the level of satisfaction. Similarly, a positive relation is observed between the "dissatisfaction" in terms of "simplicity of employment after graduation" (B29) and little importance of this variable in overall value of factor evaluation. Only separate variable in the factor 2 is the B27 "the reputation of study programmes". For the respondents, the university programmes have good reputation in the society, but it is not important aspect for them to judge the quality of study programmes. 
Figure 3. Correlation between the perceived quality of study programmes and the level of satisfaction

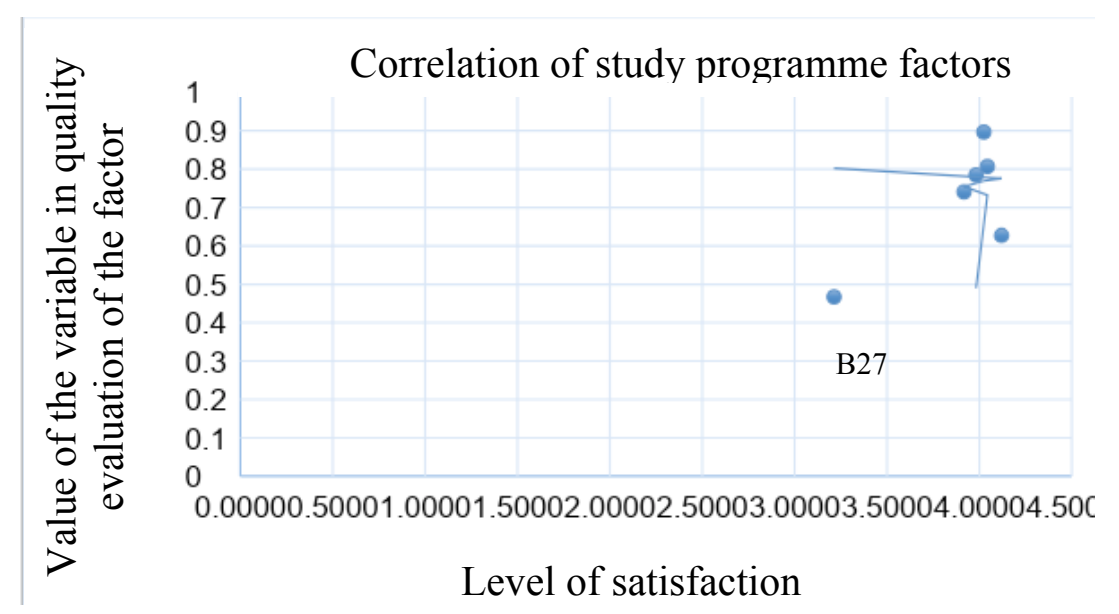

This research did not confirmed hypothesis 2 and 4 . There was insignificant difference of overall satisfaction between different faculties and student experience. (See annex 1 for more information). The hypothesis 4 that an experience in other HEI will alter the judgment of students on the quality of current institution showed very little difference in favour of first-time students in comparison with students with experiences

Table 7. Difference of satisfaction between experienced and first-time students

\begin{tabular}{|l|c|c|}
\hline $\begin{array}{l}\text { Have you ever studied in } \\
\text { other HEI then Ilia State? }\end{array}$ & Satisfaction level & $\begin{array}{c}\text { Number of } \\
\text { respondents }\end{array}$ \\
\hline No & 3.9795 & 614 \\
\hline Yes & 3.8337 & 169 \\
\hline
\end{tabular}

As for the hypothesis 3, the study showed some differences in terms of satisfaction level of different age group student, the youngest study population being the most satisfied. (See annex 1 for more information).

The hypothesis 7 on a positive correlation between satisfaction and loyalty is confirmed with this study. Students who are particularly satisfied (overall satisfaction higher than 3,8 ) are ready to continue studies at Ilia State University in future. This result shows the high expectations from students already observed at focus group meetings. Only those who judge that the quality of services proposed by the university as very good (>4.0000) are loyal to the institution. Receiving "good" services (3.000) is not enough to be loyal to their alma mater.

Table 8. Satisfaction and loyalty correlation analysis

\begin{tabular}{|l|c|c|}
\hline $\begin{array}{c}\text { In case of future studies, I will study } \\
\text { again at Ilia State University }\end{array}$ & Satisfaction level & $\begin{array}{c}\text { Number of } \\
\text { respondents }\end{array}$ \\
\hline 1. Strongly disagree & 3.1334 & 44 \\
\hline 2. Disagree & 3.3908 & 50 \\
\hline 3. I am not sure yet & 3.5440 & 134 \\
\hline 4. Agree & 3.8843 & 221 \\
\hline 5. Strongly agree & 4.3457 & 334 \\
\hline
\end{tabular}

The present study shows that average satisfaction level is not enough to guarantee students' loyalty in today' very competitive education market. This result correspondents to foreign experiences. Previous 
research by Blackmore et al. (2006) found that even whilst satisfaction ratings overall were at an acceptable level, a significant number of respondents claimed that they would not recommend their institution to others. That is why, it is particularly important for the HEI management to dig in the elements constituting students' satisfaction.

This study showed that academic elements, such as the quality of academic staff and the courses are very important component of HEI service quality. However, the quality of academic staff is even more important as it is administrative staff with whom students deal at daily basis for variety of services. Study programme reputation is another important element.

However, the respondents of this study distinguish clearly that the reputation itself can not guarantee the quality but mostly results in existing quality. For them study environment and existence of free spaces for their academic and non-academic activities is very important.

\section{Conclusion}

This paper outlines the findings of a study involving bachelor, master and doctorate level students within one Georgian university. The study showed that higher education service quality is a combination of different elements out of which the quality of administrative staff is the most important, followed closely by the quality of academic staff. The reputation of study programmes and available spaces for students' life are other essential elements.

Even if the overall satisfaction seems quite high in this study, respondents are not necessarily ready to recommend their institution or to remain loyal to it, unless they are particularly satisfied with the service quality. This observation corresponds to the findings of previous studies showing the importance of customer-orientation in increasingly competitive field of higher education. From management point of view there are obvious areas of interest where deploying resources and efforts should be targeted. These are termed as the critical areas, i.e. those that are influencing loyalty behaviours.

Evaluating service quality level and understanding how various dimensions impact overall service quality would enable HEI to efficiently design the service delivery process. In addition, knowing the strengths and weaknesses of the dimensions which influence the satisfaction level of students can result in better allocation of resources so as to provide a better service to students.

There are a number of limitations with this study. First, as the study population was selected randomly in order to guarantee an objective representation of each element, an uneven representation was observed for some variables. An absolute majority of respondents are female (86\%). Similarly, students who have no experience of studying in more than one HEI represent big majority ( $78 \%$ of the population). However. taking into account the national culture of the studied country and also the little differences observed in literature in this regard. allows to conclude that the differences would not be significant.

Future steps of this research can be undertaken in order to compare the results of this study to an international counter party. It will be interesting to observe similar trends over cultural and socio-demographic varieties.

\section{References}

Abdullah, F. 2005. "HEdPERF versus SERVPERF: The quest for ideal measuring instrument of service quality in higher education sector." Quality Assurance in Education 13(4): 305-328.

Abdullah, Firdaus. 2006. "Measuring service quality in higher education: three instruments compared." International Journal of Research and Method in Education 29(1): 71-89

Anderson E., \& Sullivan, M. 1993. "The Antecedents and Consequences of Customer Satisfaction for Firms." Marketing Science 12(2): 125-143. Retrieved from http://www.jstor.org/stable/184036.

Berger, J., \& Lyon, S. 2005. "Past to present: A historical look at retention." In A. Seidman (Ed.), College student retention. Westport: Praeger Publishers.

Bitner, M. J., Booms, B. H. \& Tetreault, M. S. 1990. "The service encounter: diagnosing favorable and unfavorable incidents." Journal of Marketing 54(1): 71-84.

Blackmore, J., Douglas, A. and Barnes, B. 2006. "Measuring student satisfaction at a UK university." Journal for Quality Assurance in Education 14(3): 251-67. 
Boulding, W., A. Karla, R. Staelin, and V.A. Zeithaml. 1993. "A dynamic process model of service quality: from expectations to behavioral intentions." Journal of Marketing Research 30(1): 7-27.

Brady, Michael K. and J. Joseph Cronin Jr. 2001. "Some new thoughts on conceptualizing perceived service quality: A hierarchical approach.” Journal of Marketing 65(3): 34-49.

Coates, Hamish. 2008. "Beyond Happiness: Managing Engagement to Enhance Satisfaction and Grades." AUSSE Research Briefing, 1, June.

Cohen L., Manion L. and Morrison K. 2007. Research Methods in Education. Routledge, 635 pages.

Coleman, S. 2005. "The Impact of Human Capital Measures on Firm Performance: A Comparison by Gender, Race and Ethnicity." The Journal of Entrepreneurial Finance \& Business Venture 10(2): 38-56.

Cook A. \& Rushton B. S. 2008. Student Transition: Practices and Policies to Promote Retention; Staff and Educational Development Association. 75 pages.

Cronin, J. Joseph Jr. and Steven A. Taylor. 1994. "SERVPERF versus SERVQUAL: Reconciling performance-based and perceptions-minus-expectations measurement of service quality." Journal of Marketing 58(1): 125-131.

Dabholkar, P. A., Thorp, D. I., \& Rentz, J. O. 1996. "A Measure of Service Quality for Retail Stores: Scale Development and Validation.” Journal of the Academy of Marketing Science 24: 3-16.

David W. Johnson D. W., Johnson R. T. \& Smith K. 2007. "The State of Cooperative Learning in Postsecondary and Professional Settings.” Educational Psychology Review 19: 15-29.

Day, R. 1977. "Consumer satisfaction, dissatisfaction and complaining behaviour.” In Symposium Proceedings, School of Business, University of Indiana.

DeShields Jr., O. W. A. Kara, and E. Kaynak. 2005. "Determinants of business student satisfaction and retention in higher education: applying Herzberg's two factor theory." International Journal of Educational Management 19(2): 128-139

Douglas, K. M., Sutton, R. M., Callan, M. J., Dawtry, R. J., Harvey, A. J. 2016. "Someone is pulling the strings: Hypersensitive agency detection and belief in conspiracy theories." Thinking \& Reasoning 22: 57-77.

El-Hilali, N., S. Al-Jaber and L. Hussein. 2014. "Students' Satisfaction and Achievement and Absorption Capacity in Higher Education." Procedia - Social and Behavioral Sciences 177: 420-427.

García-Aracil A. 2009. "European Graduates' Level of Satisfaction with Higher Education.” Higher Education 57:1-21.

Gbadosami \& De Jager. 2010. "Specific remedy for specific problems: measuring service quality in south African higher education." Higher Education 251-267.

Gemme E. 1997. "Retaining customers in managed care market." Marketing Health Services 17(3): 19-21.

Gibson, Allen. 2010. "Measuring business student satisfaction: a review and summary of the major predictors." Journal of Higher Education Policy and Management 32(3): 251-259.

Giese, Joan. L. and Joseph. A. Cote. 2000. "Defining consumer satisfaction." Academy of Marketing Science Review 1: $1-27$.

Gronroos, C. 1990. “Service Management: A Management Focus for Service Competition.” International Journal of Service Industry Management 1(1): 6-14.

Gruber, T., S. Fuss, R. Voss and M. G. Zikuda. 2010. "Examining student satisfaction with higher education services: Using a new measurement tool." International Journal of Public Sector Management 23(2): 105-123.

Hasan, H. F. A., I. Azleen, R. A. Rahman, and M. Z. A. Razak. 2008. "Service quality and student satisfaction: a case study at private higher education institutions." International Business Research 1(3): 163-175.

Herdlein R. \& Zurner E. 2015. "Student Satisfaction, Needs, and Learning Outcomes: A Case Study Approach at a European University." SAGE Open 5(2): Apr 2015.

Hill, Frances M. 1995. "Managing service quality in higher education: the role of student as primary consumer." Quality Assurance in Education 3(3): 10-21.

Hoisington, S. \& Naumann, E. 2003. "The loyalty elephant.” Quality Progress 36(2): 33-41.

Kanji, G. K., A. Malek and B. A. Tambi. 1999. “Total Quality Management in UK higher education institutions.” Total Quality Management 10(1): 129-153.

Khosravi, A. A., K. Poushaneh, A. Roozegar, and N. Sohrabifard. 2013. "Determination of Factors Affecting Student Satisfaction of Islamic Azad University." Procedia- Social and Behavioral Sciences 84 (July): 579-583.

Kotler Ph. \& Amstrong G. 2015. Principles of Marketing; Pearson Education, Limited, 731 pages.

Kumar R. 2014. Research Methodology: A Step-by-Step Guide for Beginners, SAGE, 432 pages.

Leblan G. \& Ngyuen N. 1997. Searching for excellence in business education: An exploratory study of customer impressions of service quality, International Journal of Educational Management 11(2):72-79.

Lewis. R. C. and B. H. Booms. 1983. "The Marketing Aspects of Service Quality." In Emerging Perspectives on Service Marketing. Eds. Berry, L., G. Shostack and G. Upah. 99-107. Chicago, IL. American Marketing.

Marzo-Navarro, M., M. Pedraja-Iglesias, and M. P. Rivera-Torres. 2005. "Measuring customer satisfaction in summer courses." Quality Assurance in Education 13(1): 53-65.

Meling, V., Kupczynski, L., Mundy, M., \& Green, M. 2012. "The role of supplemental instruction in success and retention in math courses at a Hispanic serving institution." Business Education Innovation Journal 4(2): $20-31$.

Mittal, V., Ross, W.T., \& Baldasare, P. 1998. The Asymmetric Impact of Negative and Positive Attribute-Level Performance on Overall Satisfaction and Repurchase Intentions. 
Ocker, R.J., \& Fjermestad, J. (1998, January). Web-based computer-medi-a ted communication: An experimental investigation comparing three communication modes for determining software requirements. Proceedings of the Thirty-First Hawaii International Conference on System Sciences, Hawaii.

Othman \& Owen. 2001. "Adopting and Measuring Customer Service Quality (SQ) in Islamic Banks: A Case Study in Kuwait Finance House.” International Journal of Islamic Financial Services Vol. 3(1).

Pallant J. 2001, SPSS Survival Manual. A step by step guide to data analysis using SPSS for Windows (Version 10). Open University press. 290 pages.

Parasuraman, A. P., V. A. Zeithaml, and L. L. Berry. 1988. "SERVQUAL: A multiple-item scale for measuring consumer perceptions of service quality." Journal of Retailing 64(1): 12-37.

Ping, C. J. 1999. "An expanded international role for student affairs." In: Beyond borders: How international developments are changing student affairs practice: New Directions for Student Services. Ed. Dalton, J. C. No. 86. 13-21. San Francisco, CA: Jossey-Bass.

Quinn, A., G. Lemay, P. Larsen and D. M. Johnson. 2009. "Service quality in higher education." Total Quality Management \& Business Excellence 20(2): 139-152.

Randheer K. 2015. "Service Quality Performance Scale in Higher Education: Culture as a New Dimension." International Business Research 8(3): 29-41.

Rode, J., Arthaud-Day, M., Mooney, C., Near, J., Baldwin, T., Boomer, W., \& Rubin, R. 2005. "Life satisfaction and student performance." Academy of Management Learning \& Education 4(4): 421-33.

Rust, R. T., \& Oliver, R. L. 1994. Service Quality: Insights and manegerial implications from the frontier in Service Quality: New directions in theory and practice (pp. 1-19): Sage Publication.

Smith, R. A. and M.J. Houston. 1982. "Script-based evaluations of satisfaction with services." In Emerging Perspective on Services Marketing. Eds. Berry, L., G. Shostack and G. Upah. 59-62. Chicago. American Marketing Association.

Temizer, Leyla and Ali Turkyilmaz. 2012. "Implementation of Student Satisfaction Index Model in Higher Education Institutions." Procedia - Social and Behavioral Sciences 46: 3802-3806.

Thompson Lemaro R. and Leon C. Prieto. 2013. "Improving retention among college students: Investigating the utilization of virtualized advising." Academy of Educational Leadership 17(4): 13-26.

Vazirova, Narmina. 2016. Measuring Service Quality in Higher Education: A Study of Post-Graduate Students in Northern Cyprus.

Zaheer B. \& Rehman K. 2010. “A study examining the students satisfaction in higher education." Social and Behavioral Sciences 2(2): 5446-5450.

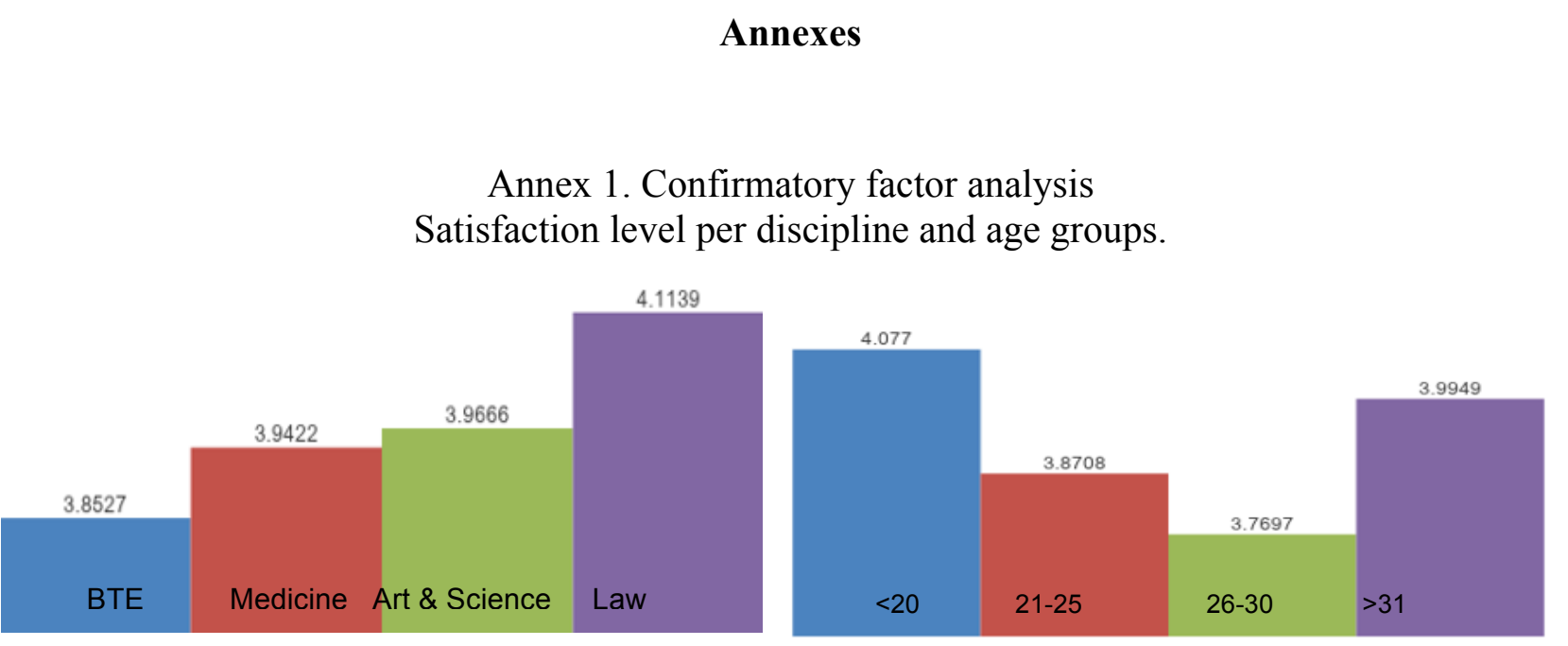

Annex 2. Open question results from the survey

Positive elements with chronological order Negative elements with chronological order (from the most cited till the least):

1. Free environment (from the most cited till the least):

1. Lack of student spaces for individual and teamwork, and for sports 


\begin{tabular}{|c|c|}
\hline 2. Flexible online platform ARGUS & $\begin{array}{l}\text { 2. Discrepancy between the study programmes } \\
\text { and the market demand }\end{array}$ \\
\hline $\begin{array}{l}\text { 3. Modern infrastructure and well-equipped } \\
\text { classrooms }\end{array}$ & 3. Lack of practice-oriented courses \\
\hline 4. Well-equipped and modernized library & 4. Oversized study groups \\
\hline 5. Qualified and practitioner academic staff & $\begin{array}{l}\text { 5. Little difference between master and } \\
\text { bachelor degree programmes }\end{array}$ \\
\hline $\begin{array}{l}\text { 6. Employment and work placement } \\
\text { possibilities }\end{array}$ & 6. Issues with evaluation system \\
\hline 7. High quality public classes & 7. Technical difficulties during class selection \\
\hline $\begin{array}{l}\text { 8. Diversity of student activities (extra } \\
\text { curriculum) }\end{array}$ & $\begin{array}{l}\text { 8. Lack of computer rooms and limited } \\
\text { working hours }\end{array}$ \\
\hline 9. Non mandatory class attendance & 9. Slow internet \\
\hline $\begin{array}{l}\text { 10. Possibility to retake missed classes and } \\
\text { exams }\end{array}$ & 10. Lack of security systems \\
\hline
\end{tabular}

